\title{
Efficacy of Bacterial Collagenase Therapy in RFM Cows Assesed through Concentration of Serum and Lochial NAGase
}

\author{
P. Mohan ${ }^{1 *}$, K. Krishnakumar ${ }^{2}$, K. Kulasekar ${ }^{3}$, S.M.K. Karthickeyan ${ }^{4}$ and \\ M. Murugan ${ }^{5}$ \\ ${ }^{1}$ Department of Veterinary Gynaecology and Obstetrics, Veterinary College, \\ Shivamogga -577 204, KVAFSU, India \\ ${ }^{2}$ Cattle and Buffalo Breeding Unit, PGRIAS, Kattupakkam- 603203, India \\ ${ }^{3}$ Department of Clinics, Madras Veterinary College, Vepery- 600 007, India \\ ${ }^{4}$ Department of Animal Breeding Genetics, Madras Veterinary College, \\ Vepery-600 007, India \\ ${ }^{5}$ VUTRC, Melmaruvathur, India \\ *Corresponding author
}

\section{A B S T R A C T}

The study was conducted in cases of RFM presented within 12 to 24 hours after parturition to Obstetrics Unit of Madras Veterinary College, Chennai. Group I received placebo treatment with one litre of normal saline intravenously. Group II cows, treated with

\section{Keywords}

Serum, Uterine lochial NAGase, RFM, bacterial collagenase Efficacy, Cows

Article Info

Accepted: 06 September 2018 Available Online: 10 October 2018 intrauterine proteolytic bolus containing nitrofurazone, metronidazole and urea and antibiotic therapy (Inj. Streptopenicillin @ 20,000 units/kg body weight) without manual removal for 7 days. Groups III cows, received single dose of 2, 00,000 CDU of collagenase plus $40 \mathrm{mg}$ of calcium chloride and $40 \mathrm{mg}$ of sodium bicarbonate dissolved in one litre of normal saline at a $\mathrm{pH}$ of 7.5 intravenously through jugular vein (Eiler and Hopkins, 1993). Group IV received single dose of 2,00,000 U of collagenase intravenously. The data on the concentration of serum and lochial NAGase of all the different treatment groups with serum and lochia samples were collected. Further, collected data were compared and analyzed; which showed that the serum NAGase concentration was significantly $(\mathrm{P}<0.01)$ higher in group IV on day 0 ; group II on day 7; group II and IV on day 14; and the overall mean concentration was significantly $(\mathrm{P}<0.05)$ lower in groups I and III. The lochial NAGase concentration was significantly $(\mathrm{P}<0.05)$ higher in group IV on day 0 and group II on day 7 and 14. These results revealed that the administration of collagenase through intravenous route had achieved better healing and recovery.

\section{Introduction}

If the placenta is retained longer than 8 to 12 $\mathrm{h}$, it is considered pathological and referred as retention of foetal membrane (Hanafi et al.,
2011). The incidence of retained foetal membrane (RFM) varies from 4 to16 per cent in cattle (Hossein and Ardalam, 2011), which leads to reduced milk yield, endometritis and poor fertility. 
A variety of methods have been used in the treatment of RFM, which includes manual removal and / or administration of oxytocin, $\mathrm{PGF}_{2 \alpha}$, antibiotics, immunomodulators etc., although the efficacy of these treatments are questionable (Eiler, 1997). The alternate route for the collagenase administration instead of umbilical arteries was reported by Eiler and Hopkins (1993) that the dose of $2.2 \times 10^{6} \mathrm{U}$ in $1000 \mathrm{ml}$ physiological saline solution over a period of $30 \mathrm{mts}$ through jugular vein. The mean serum NAGase concentration on days 5 and 32 postpartum was 174.75 and $109 \mathrm{u} / \mathrm{l}$, respectively in normal puerperium and 264 and $175 \mathrm{u} / \mathrm{l}$, respectively in abnormal puerperium and the overall mean serum NAGase concentration was 150.73 and 215.22 $\mathrm{u} / \mathrm{l}$, respectively in normal and abnormal puerperium in dairy cows (Hussain et al., 1989).

The mean concentration of NAGase in uterine fluid on day 5 postpartum was significantly higher as 3501 and $3027 \mathrm{u} / 1$ in normal and abnormal puerperium, respectively and declined at lowest value on day 32 postpartum in cows and overall mean uterine fluid NAGase concentration was 2005.78 and $1911.03 \mathrm{u} / \mathrm{l}$ in normal and abnormal postpartum, respectively, which revealed that NAGase level have been suggested for use in monitoring uterine involution in cows (Hussain et al., 1989).

The collagenase administration through umbilical artery is the effective treatment for RFM in dairy cows; however, such collagenase treatment is costly and administration through the umbilical cord is more difficult after $48 \mathrm{hrs}$. Hence, the study was formulated to determine the effect of collagenase through intravenous route instead of umbilical arteries. Further, the efficacy of different treatment regimens was studied and the healing processes were assessed through the estimation of serum and lochial NAGase.

\section{Materials and Methods}

Fifty two healthy and parous cows less than 10 years of age, presented to the Large Animal Obstetrics Unit, Teaching Veterinary Clinical Complex, Madras Veterinary College, Chennai-7 were utilized for the study. Seven healthy cows with normal calving and shedding of placenta were served as group I (control) and treated with one litre of normal saline intravenously. Thirty cows with unassisted calving followed by retained foetal membranes between 12 and $24 \mathrm{~h}$ interval were selected and randomly allotted into groups II and III of fifteen each. Fifteen cows with difficulty in parturition followed by RFM were considered as group IV.

Group II cows, treated with intrauterine proteolytic bolus containing nitrofurazone, metronidazole and urea and antibiotic therapy (Inj. Streptopenicillin @ 20,000 units/kg body weight) for 7 days without manual removal. Groups III and IV cows, received single dose of 2, 00,000 CDU of collagenase plus $40 \mathrm{mg}$ of calcium chloride and $40 \mathrm{mg}$ of sodium bicarbonate dissolved in one litre of normal saline at a $\mathrm{pH}$ of 7.5 intravenously through jugular vein (Eiler and Hopkins, 1993).

\section{Serum separation}

The collected blood samples were allowed to clot at room temperature and centrifuged at $3000 \mathrm{rpm}$ for 10 minutes. Serum was separated and stored at $-20^{\circ} \mathrm{C}$ until estimation of serum biochemical parameters.

\section{Collection of lochia}

Thirty $\mathrm{ml}$ of uterine lochia was collected on days 0,7 and 14 postpartum with the help of Ramson's children's enteral feeding tube and kept in a sterile screw capped and stored at $20^{\circ} \mathrm{C}$ until estimation of NAGase. Remaining part of the lochia was immediately utilized for 
cytological and bacteriological study (Cruikshank et al., 1974) in all the groups.

\section{Preparation of lochial filterant for NAGase estimation}

One $\mathrm{ml}$ of lochia was diluted with $10 \mathrm{ml}$ of ice cold phosphate buffered saline (PBS $0.01 \mathrm{M}$, $\mathrm{pH}$ 7.2), mixed gently and centrifuged at 800 rpm for 30 minutes. The clear lochial filterant supernatant solution was collected and stored at $-20^{\circ} \mathrm{C}$ until the estimation of NAGase (Hussain et al., 1989).

\section{NAGase}

The serum NAGase concentration was estimated using commercial ELISA kit supplied by Sigma Aldrich, U.S.A.

\section{NAGase}

The lochial supernatant solutions stored at $20^{\circ} \mathrm{C}$ was used for the estimation of lochial NAGase with commercial ELISA kit supplied by Sigma Aldrich, U.S.A.

\section{Statistical analyses}

The accumulated data were statistically analyzed as per the procedure described by Snedecor and Cochran (1994) and by one way ANOVA

\section{Results and Discussion}

The serum NAGase concentration on day 14 postpartum was significantly $(\mathrm{P}<0.05)$ lower in groups I and III than the remaining groups (Table 1 and Figure 1). These findings in the present study revealed that the concentration of NAGase enzyme with the joint action of exogenously administered collagenase is essential for the proper release of foetal membranes (Kankofer et al., 2000). Further, the overall mean concentration of NAGase was significantly $(\mathrm{P}<0.01)$ lower in groups I and III than the groups II and IV. These results in the present study might be due to severe tissue damage occuring while handling dystocia in group IV and severe irritation, inflammation and damage to the endometrium caused by the intrauterine proteolytic drugs in group II was responsible for the lysis of epithelial cells and leucocytes resulted in the release of higher concentration of NAGase (Larsen and Aulrich, 2012), which might be the reason for the delayed placental separation in group II and IV. Hence, the higher concentration of NAGase has been utilized as a marker for rapid test for predicting the severity of infection (Chaquanda et al., 2006) and inflammation (Polat et al., 2010).

The trend of decreasing concentration of lochial NAGase towards increasing days of postpartum (Table 2 and Figure 2) were similar to that of serum NAGase in the present study. These findings concurred with the observations of Hussain et al., (1989) that the mean concentration of NAGase in uterine fluid on day 5 postpartum $(3501 \mathrm{u} / \mathrm{l})$ was significantly $(\mathrm{P}<0.01)$ higher and declined at lowest value on day $32(2005.78 \quad$ u/l $)$ postpartum in cows.

The mean ( \pm SE) lochial NAGase concentration on days 0,7 and 14 in all the groups were ten times higher than the serum NAGase concentration. Similar findings were recorded by Hussain et al., (1989) that the uterine fluid NAGase concentration on day 5 postpartum was $2005.78 \mathrm{u} / \mathrm{l}$ in normal puerperium; whereas, the serum NAGase concentration was $150.77 \mathrm{u} / \mathrm{l}$.

It was concluded that the endometrial tissues were considered as active source of NAGase release (Hussain and Daniel, 1992) and might be the reason for the higher concentration of NAGase present in the uterine fluid than the serum. 
Table.1 Mean $( \pm$ SE) Serum NAGase concentration during different phases of postpartum with different Treatment regimens of RFM cows

\begin{tabular}{|l|l|l|l|l|}
\hline & \multicolumn{5}{|c|}{ Group/Days } & $\mathbf{0}$ & $\mathbf{7}$ & $\mathbf{1 4}$ & Overall mean \\
\hline I $(\mathbf{n}=7)$ & $247.10 \pm 7.94^{\mathrm{aC}}$ & $205.70 \pm 14.23^{\mathrm{aB}}$ & $149.28 \pm 15.43^{\mathrm{aA}}$ & $208.94 \pm 12.05^{\mathrm{a}}$ \\
\hline II $(\mathbf{n = 1 5})$ & $251.70 \pm 11.83^{\mathrm{aB}}$ & $247.16 \pm 10.60^{\mathrm{bB}}$ & $198.41 \pm 7.72^{\mathrm{cA}}$ & $231.67 \pm 8.23^{\mathrm{c}}$ \\
\hline III $(\mathbf{n = 1 5})$ & $266.44 \pm 17.23^{\mathrm{aC}}$ & $212.01 \pm 12.99^{\mathrm{aB}}$ & $154.68 \pm 11.58^{\mathrm{aA}}$ & $198.85 \pm 8.23^{\mathrm{a}}$ \\
\hline IV $(\mathbf{n}=15)$ & $277.10 \pm 7.94^{\mathrm{bC}}$ & $219.19 \pm 13.86^{\mathrm{aB}}$ & $176.49 \pm 13.32^{\mathrm{bA}}$ & $213.40 \pm 8.23^{\mathrm{b}}$ \\
\hline
\end{tabular}

Means bearing different superscripts $(A-B)$ in each row differ significantly $(P<0.01)$

Means bearing different superscripts $(a-b)$ in each column differ significantly $(P<0.01)$

Table.2 Mean $( \pm$ SE) lochial NAGase concentration during different phases of postpartum with different Treatment regimens of RFM cows

\begin{tabular}{|c|c|c|c|c|}
\hline \multirow[t]{2}{*}{ Group/Days } & \multicolumn{4}{|c|}{ NAGase $(u / l)$ concentration } \\
\hline & $\mathbf{0}$ & 7 & 14 & Overall mean \\
\hline $\mathrm{I}(\mathrm{n}=7)$ & $2916.26 \pm 65.16^{\mathrm{aC}}$ & $1781.55 \pm 128.94^{\mathrm{aB}}$ & $1233.39 \pm 35.99^{\mathrm{aA}}$ & $1972.37 \pm 55.86^{\mathrm{a}}$ \\
\hline II $(\mathbf{n = 1 5})$ & $3121.69 \pm 83.51^{\mathrm{bB}}$ & $2410.91 \pm 79.68^{\mathrm{cA}}$ & $2231.29 \pm 124.46^{\mathrm{cA}}$ & $2411.51 \pm 55.86^{\mathrm{C}}$ \\
\hline III $(n=15)$ & $3118.51 \pm 83.29^{\mathrm{bC}}$ & $2005.29 \pm 117.73^{\mathrm{bB}}$ & $1260.01 \pm 66.47^{\mathrm{a} A}$ & $2082.16 \pm 55.86^{\mathrm{a}}$ \\
\hline IV $(n=15)$ & $3281.17 \pm 48.01^{\mathrm{cC}}$ & $2105.83 \pm 94.80^{\mathrm{bB}}$ & $1436.05 \pm 18.52^{\mathrm{bA}}$ & $2186.85 \pm 81.78^{b}$ \\
\hline
\end{tabular}

Means bearing different superscripts (A-B) in each row differ significantly $(\mathrm{P}<0.01)$

Means bearing different superscripts $(\mathrm{a}-\mathrm{b})$ in each column differ significantly $(\mathrm{P}<0.01)$ 
Fig.1 Serum NAGase concentration during different phases of postpartum with different treatment regimens of RFM cows

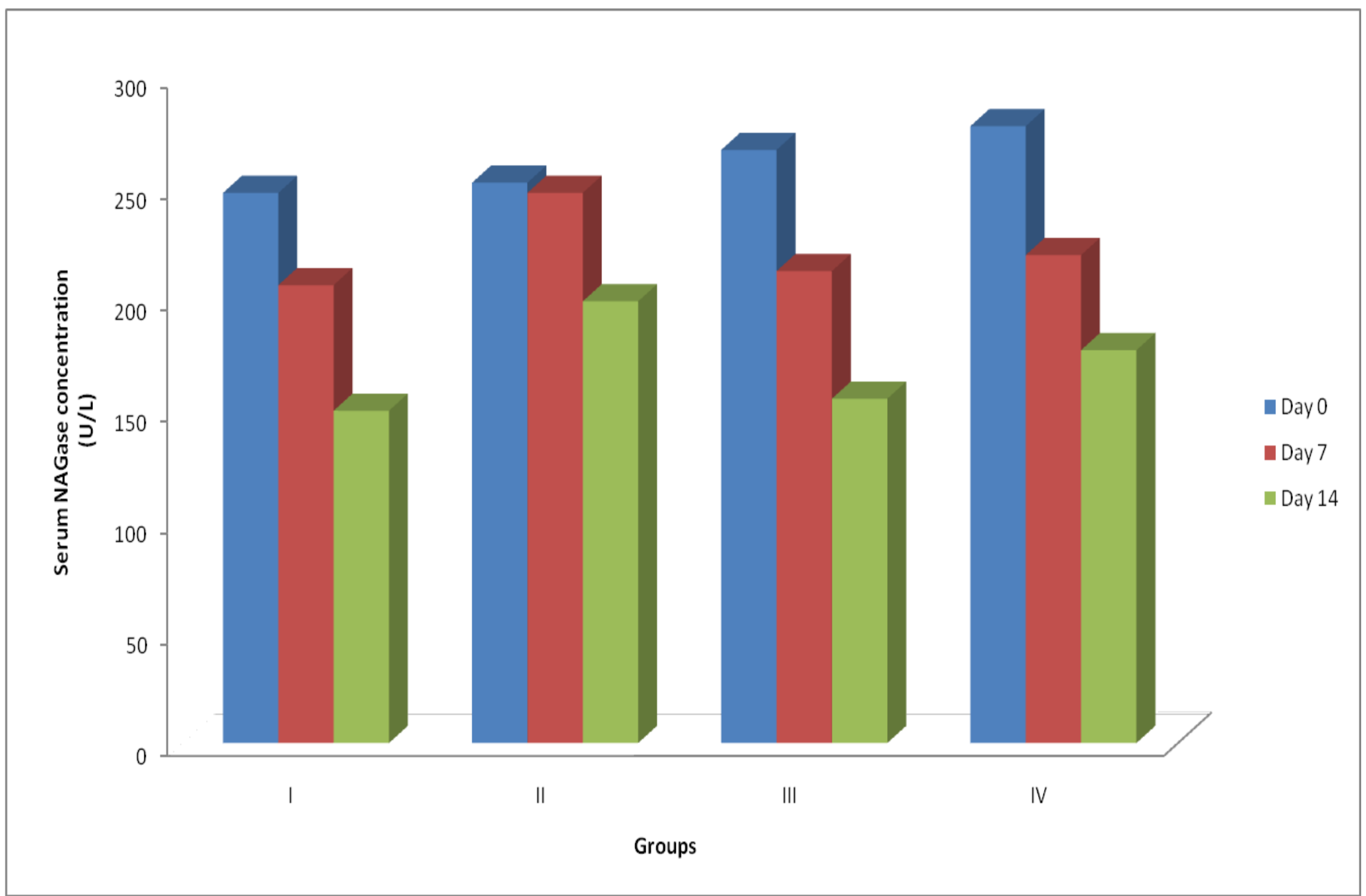


Fig.2 Lochial epithelial cell count during different phases of postpartum with different treatment regimens of RFM cows

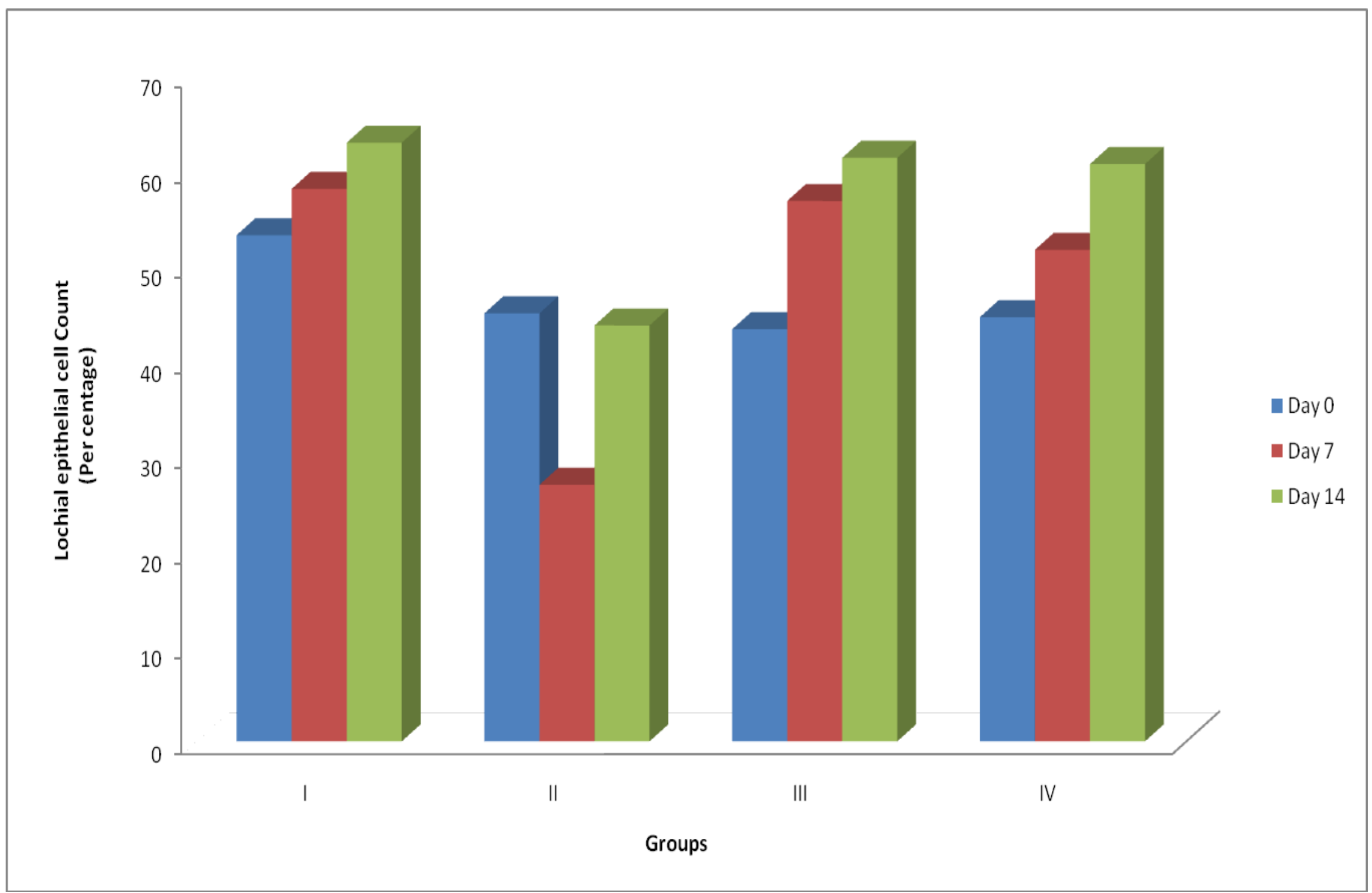


The lochial NAGase concentration on day 0 was significantly $(\mathrm{P}<0.05)$ higher in group IV $(3281.17 \pm 48.01 \mathrm{u} / \mathrm{l})$ than the remaining groups. However, group $(3121.69 \pm 83.51 \mathrm{u} / \mathrm{l})$ and III (3118.51 $\pm 83.29 \mathrm{u} / \mathrm{l})$ had significantly $(\mathrm{P}<0.01)$ higher concentration of NAGase than group I $(2916.26 \pm 65.16 \mathrm{u} / \mathrm{l})$. These findings were in contrast to the observations of Hussain et al., (1989) that the mean concentration of NAGase in uterine fluid was significantly $(\mathrm{P}<0.01)$ higher in normal puerperium $(3501 \mathrm{u} / \mathrm{l})$ than abnormal puerperium $(3027 \mathrm{u} / \mathrm{l})$ in dairy cows.

On day 7 , the lochial NAGase concentration was significantly $(\mathrm{P}<0.01)$ higher in group II $(2410.91 \pm 79.68 \mathrm{u} / \mathrm{l})$ than groups I $(1781.55$ $\pm 128.94 \mathrm{u} / \mathrm{l})$, III $(2005.29 \pm 117.73 \mathrm{u} / \mathrm{l})$ and IV $(2105.83 \pm 94.80 \mathrm{u} / \mathrm{l})$. Further, group I had significantly $\quad(\mathrm{P}<0.01) \quad$ lower NAGase concentration than groups III and IV; however, group III and IV did not have any significant difference.

These findings revealed that the acute inflammation in the uterus was responsible for the release of high concentration of lochial NAGase (Tizard, 1996). These might be the reason for the elevated NAGase concentration in group II.

On day 14, the lochial NAGase concentration was significantly $(\mathrm{P}<0.01)$ higher in group II $(2231.29 \pm 124.46 \mathrm{u} / \mathrm{l})$ than the remaining groups. However, group IV (1436.05 \pm 18.52 $\mathrm{u} / \mathrm{l})$ had significantly $(\mathrm{P}<0.01)$ higher concentration of lochial NAGase than groups I $(1233.39 \pm 35.99 \mathrm{u} / \mathrm{l})$ and III (1260.01 \pm $66.47 \mathrm{u} / \mathrm{l})$; whereas, group I and III did not differ significantly. In group III and IV, the administration of 2, 00,000 CDU of collagenase through intravenous route was responsible for the easy separation of placenta, complete evacuation of lochia, reduced bacterial load and leucocytic count, resulted in reduced concentration of NAGase.
Hence, the estimation of NAGase in the uterine fluid / serum has been suggested in monitoring uterine involution (Hussain et al., 1989) and utilized as a rapid test for predicting the severity of inflammation (Chaquanda et al., 2006) further, it was concluded that the serum NAGase concentration was significantly $(\mathrm{P}<0.01)$ higher in group IV on day 0 ; group II on day7; group II and IV on day 14; and the overall mean concentration was significantly $(\mathrm{P}<0.05)$ lower in groups I and III.

\section{Acknowledgement}

The author expresses thanks to Department of clinics, Madras Veterinary College, and TANUVAS for providing all the facilities to carry out the research.

\section{References}

Chaquanda, M. G., T. Larsen, M. Bjerrinq and K. L. Ingvartsen (2006). L-lactate dehydrogenase and N-acetyl-3-DGlucosaminidase activities in bovine milk as indicators of non-specific mastitis. J. Dairy Res., 73: 431-440.

Cruickshank, R., J.P. Duguid, B.P. Marinion and R.H.A. Swain (1974). In: Medical microbiology, $8^{\text {th }}$ Edn., The English Language Book Society and Churchill Livingstone, U.K.

Eiler, H (1997). Retained placenta. In: Current therapy in large Animal Theriogenology. W.B. Sounders Company, Philadelphia, Pp. 340-348.

Eiler, H and F. M. Hopkins (1993).Successful treatment of retained placenta with umbilical cord injections of collegenase in cows. J. Am. Vet. Med. Assoc., 203: 436-443.

Hanafi, E.M., W.M. Ahmed, H.H. E.L. Khadrawy and M.M. Zabal (2011). An overview on placental retention in farm 
animals. Middle East J. Sci. Res., 7: 643-651.

Hossein, N.G and M. Ardalam (2011). Cowspecific risk factors for retained placenta, metritis and clinical mastitis in Holstein cows. Vet. Res. Commun., 35: 345-354.

Hussain, A. M and R. C. W. Daniel (1992). Phagocytosis by uterine fluid and blood neutrophils and hematological changes in postpartum cows following normal and abnormal parturition.42: Therogenology, 1253-1267.

Hussain, A. M., R. C. W. Daniel and D. O'Boyle (1989). N-Acetyl- $\beta$-DGlucosaminidase activity in bovine uterine fluid and blood serum during postpartum period. Theriogenology, 32: 507- 514

Kankofer, M., J. Wiereinski and H. Zerbe (2000). Activity of placental $\beta-\mathrm{N}$ -
Acetyl- Glucosaminidase in cows with and without retained fetal membranes. Reprod. Dom. Anim., 35: 97-100.

Larsen, T and K. Aulrich (2012). Optimizing the fluorometric beta-glucuronidase assay in ruminant milk for a more precise determination of mastitis. $J$. Dairy Res., 79: 7-15.

Polat, B., A. Colak, M. Cengiz, L.Yanmaz, H. Oral, A. Bastan, S. Kaya and A. Hayirli (2010). Sensitivity and specificity of infrared thermography in detection of subclinical mastitis in dairy cows. $J$. Dairy Sci., 93: 3525-3532.

Snedecor, G.W and W.G. Cochran (1994). Statistical methods, $8^{\text {th }}$ Edn., Iowa State University Press, U.S.A.

Tizard, I. R. (1996). Veterinary immunology. An introduction. $5^{\text {th }}$ Edn., W.B. Saunders, Philadelphia, Pp. 531.

\section{How to cite this article:}

Mohan, P., K. Krishnakumar, K. Kulasekar, S.M.K. Karthickeyan and Murugan, M. 2018. Efficacy of Bacterial Collagenase Therapy in RFM Cows Assesed through Concentration of Serum and Lochial NAGase. Int.J.Curr.Microbiol.App.Sci. 7(10): 769-776.

doi: https://doi.org/10.20546/ijcmas.2018.710.085 